\title{
The COVID-19 Virus Wears Stiletto: Review of Gendered Socio-economic Impacts and Implications of the Coronavirus Pandemic on Women and Girls in Zimbabwe
}

\section{Ruvarashe Chigiya-Mujeni ${ }^{\circ}$}

PhD Scholar, College of Peace, Leadership and Governance, Africa University, Africa (chigiyar@ africau.edu)

Received: 02 July, 2020

Revised: 17 October, 2020

Accepted: 18 November, 2020

Published: 15 December, 2020

How to cite this paper: ChigiyaMujeni, R. (2020). The COVID-19 virus wears stiletto: Review of gendered socio-economic impacts and implications of the corona virus pandemic on women and girls in Zimbabwe. Quest Journal of Management and Social Sciences, 2(2), 371-378.

Copyright $(\mathbb{C} 2020$ by authors and Quest Journal of Management and Social Sciences.

This work is licensed under a Creative Commons Attribution-Non Commercial-No Derivatives 4.0 International License.

https://creativecommons.org/

licenses/by-nc-nd/4.0/

\section{Abstract}

Background: With its ability to mutate and take charge of its hosts' respiratory organs, COVID-19 has ravaged the global north and south alike. The world's greatest economies are crumbling and death tolls continue to rise exponentially. The most recent strain of the coronavirus has spread like wildfire, sparing neither the rich nor the poor. It is pertinent, however, to note that natural disasters do not affect members of society unilaterally. Women, children and the disabled interact with global and national disasters differently, highlighting the urgent need to take cognizance of the various elements that constitute the measures drafted and implemented to tackle the spread and impact of these disasters.

Objective: This paper seeks to demonstrate these intricacies based on the webinar held in March 2020 by UN Women in Zimbabwe and discuss the impact and implications of this virus on women and girls in Zimbabwe and bring out the challenges faced as they fight the virus in various socioeconomic settings.

Methods: A desk review approach was used to highlight the various gender dimensions surrounding the coronavirus and its implications on women and girls in Zimbabwe.

Results: Women, due to their multiple gendered roles and biological dispositioin, are impacted differently by COVID-19. Women are also, therefore, more vulnerable to succumb to the virus.

Conclusions: There is a need to take a holistic approach in dealing with issues of the pandemic without ignoring the fact that women are on the receiving end.

Implications: This paper is useful to policy makers, institutions working on COVID-19 and government to take necessary actions.

Originality: This paper is original and not sent anywhere else for publication.

Paper Type: Review Paper

Keywords: Coronavirus, COVID-19, Women, Zimbabwe

JEL Classification: I14, I15, I18, L3, J16 


\section{Introduction}

COVID-19, which was first reported from the Chinese city of Wuhan, has left an indelible mark on the globe since its discovery in December 2019. Governments in both developed and developing countries have established a variety of responsive measures to manage the spread of the virus and subsequent human and economic casualties. While some governments rapidly adopted highly stringent and draconian lockdown measures to curb the spread of the virus, others were more passive, opting instead to continue economic activity. This variability, along with the unpredictable nature of the behaviour of the virus itself has led to varying degrees of success and failure in tackling the respiratory illness. Generally, a combination of measures such as lockdown, restricting the free movement of people, social distancing, restrictions on domestic and international travel, quarantine of in-bound citizens and visitors, washing of hands, wearing of protective clothing like face masks, have been widely adopted as responsive measures with varying levels of intensity and enforcement. These measures, however, come with their own complexities as the contexts within which they are to be applied vary from state to state, and from government to government both in terms of capacity and commitment.

Following suit with the international community, the Zimbabwean government launched a National Response Plan on the 17th March 2020 and declared the COVID 19 outbreak a national disaster following the confirmation of the death of one citizen. The Plan was premised on the prevention of the spread of the infection, safeguarding lives through the minimisation of physical contact, and infrastructural development of the health care sector in preparation of any impending outbreak. However, the rapid implementation of the Plan did not take into consideration the contextual uniqueness of the Zimbabwe's socioeconomic environment, which resulted in a variety of externalities chief among them, a significant and rapid increase in unemployment, loss of livelihood, and reports of gender-based violence (GBV). In light of this, global and international agencies have sought to highlight the need for measures introduced to manage a national disaster within the bounds of contextualisation. Within the Zimbabwean context, as is the context of this paper, the impacts of COVID-19 control measures do not take into consideration their effects on the livelihoods, health and security of women, representing a non-gender sensitive response to a global epidemic. In response to this, the UN Women Agency in Zimbabwe facilitated a webinar meeting in which different ministries and agencies participated to discuss the gendered socio economic impacts and implications of the COVID-19 pandemic and how different stakeholders can lend their insight and expertise to the refurbishment and further development of a multi-sectoral approach to COVID-19 alleviation. It is thus the aim of this paper to discuss these gender dimensions of the social and economic impact of this pandemic on the women and girls in Zimbabwe.

This paper is structured as follows: it first examines the impact and implications Covid 19 on women and girls in Zimbabwe. Secondly it will look at measures proposed and implemented by the government and private sector in varying attempts to mitigate the impacts of the virus. Finally, it will propose socially inclusive measures that may reduce the burden this group carries as they join the world in fighting against this pandemic.

\section{Review of Literature}

\section{COVID-19 and Its Impact on Women}

According to a United Nations Population Fund (UNFPA) technical brief (2020), be it pandemics or disease outbreaks, women and men are affected differently. Pandemics such as COVID-19 amplify existing inequalities for women, girls and other marginalised groups such as persons with disabilities and those in extreme poverty. In a UN Policy Brief (2020), the UN Secretary-General António Guterres highlighted that across every sphere, from health to the economy, security to social protection, the impacts of COVID-19 are exacerbated for women and girls simply by virtue of their gender. This is 
in part due to the jobs women fill, the gender pay gap, and the large burden of unpaid childcare and housework. Daphne Serumaga and Pamela Mhlanga from the UN Women supported this view during the webinar meeting and highlighted that because of these already existing gender inequalities there was need to put on a gender lens so as to understand the different impacts of this pandemic on women and girls in Zimbabwe. They pointed to the fact that women and girls are front line responders and play a major role in the home. This background puts them at high risk and exposure during the Coronavirus pandemic.

The nurturing role played by women leaves them highly exposed during any pandemic since they are the ones who generally take care of the sick in the home in patriarchal societies like Zimbabwe. This leads to significant levels of stress and burden especially in the African context where traditionally household chores are not evenly distributed. After taking care of the sick, girls and women are expected to do and carry on with the normal household duties like cooking, cleaning, and bathing the children. This results in women being highly stressed, weak, and pressurised and more prone to contamination of the virus. This unequal burden for caregiving further hampers women's ability to participate fully in any other paying activities. In a UNESCO Report, Giannini (2020) asserted that "as COVID-19 forces school closures in 185 countries, Plan International and UNESCO warn of the potential for increased drop-out rates which will disproportionately affect adolescent girls, further entrench gender gaps in education and lead to increased risk of sexual exploitation, early pregnancy and early and forced marriages. Shutting down of schools has disrupted studies and increased the burden on female students and young girls as they are being forced to be full time care workers, limiting their time to focus on studies and school work. A 2018 report by the International Labour Organization discovered that globally, women perform 76.2 percent of unpaid care work, more than three times as much as men and this, "unpaid care work is the main barrier preventing women from getting into, remaining and progressing in the labour force".

Daphne Serumaga also highlighted that during the COVID-19 global pandemic women stand a chance of being subjected to abject poverty due to interruptions in the economic activity. Governments in the developing world replicated measures put down by European countries to curb the spread of the virus without taking into consideration their local circumstances; failing economies, poor health systems, high inflation rates and high unemployment rate. These countries depend on the informal sector with a significant percentage of their population living below the poverty datum line. These challenges have not spared Zimbabwe which has approximately 62.3 percent of its population in the informal sector. Women in the informal sector usually engage in cross border trading, vending, operating hair salons and domestic workers. These kinds of jobs in the informal sector are characterised by inconsistent revenue and hand-to-mouth lifestyles which is unsustainable during stringent lockdown conditions. Those formally employed in the private sector are being asked to take unpaid leave while those in the public service earn meagre salaries resulting in a significant portion of the population living below the poverty datum line. Further, these jobs in the informal sector do not allow social distancing or self-isolation and cannot be practised during the COVID-19 lockdown exercise. This means a loss of income for women in this group who are left with the burden to look after their families without any source of income and funding. Female headed household suffer immensely since no income will be received during the whole period of lockdown. In addition, the nature of work in the informal sector, does not allow any form of savings, insurance or health cover to cushion or cater for their loved ones during such unexpected occurrences such as the COVID-19 outbreak.

It is also notable that these challenges are not unique to Zimbabwean women only, but, as women of colour globally as Forde 2020 states, "Women of colour in particular could suffer disproportionately from virus-fuelled economic downturn." According to an analysis by the World Economic Forum, Beech (2020), women jobs pay less than men and hence are poised to lose more from the continuing economic fallout of an epidemic or national disaster. Again because of economic interruptions and 
measures put down by governments to curb the spread of the coronavirus, some companies are downsizing while others are shutting down completely. "The sectors dominated by women workers, including textiles and the service industry, have been the first hit." In Bangladesh, more than a million garment works have been laid off, 80 percent of them women. According to the U.S. Department of Labor, nearly 60 percent of the jobs eliminated in the first wave of pandemic cuts were held by women" (Coleburn et al: 2020). In Zimbabwe, during the second level of lockdown, only the formal sector was allowed to return to work and the informal sector remained closed. Established retailers like OK and TM supermarkets were only allowed to open and listed under essential services from the onset of the lockdown period. Baby product stores and sanitary shops, were not listed under essential services and were subsequently closed. It was therefore very difficult to access diapers, baby formula, cereal, or any other baby products in these supermarkets especially in the high density, and most of these shops had run out of these products by the fifth week of lockdown. This has resulted in the emergence of a black market of essential goods which may be exorbitantly priced and pose a health risk to women and those who are forced to resort to them.

The COVID-19 virus, with its raft of lockdown measures, has also caused shortages of basic commodities in the market and this in turn has resulted in sharp increase of prices of these commodities. Women, as household food managers, are at the frontline of the negative impacts of sharply increased prices of basic commodities and are left with an unbearable pressure to balance and put food on the table for their families. However, because of women's nurturing role again when the food is inadequate, they tend to feed their young ones first. In the end they either go hungry or consume left overs which may not be of any nutritional value. Pamela Mhlanga said this leads to malnutrition and poor immune system hence increasing women's chance of exposure to contamination and inability to fight off the virus if contaminated.

The duo from UN Women Zimbabwe also highlighted that there has been an increase in gender-based violence (GBV) and intimate partner violence attributed to lockdowns within the 2019-20 coronavirus pandemic. This has been caused by a number of factors but mainly poverty and stress during lockdown period. This point was supported in a report drafted by Kirsty Johnson (2020) of the New Zealand Times which read, "Financial insecurity, stress, and uncertainty have led to increased aggression at home, with abusers able to control large amounts of their victims' daily life." The United Nations Secretary-General António Guterres has since called for an end to all forms of conflict including domestic violence and issued a statement encouraging governments to put women's safety first as they respond to COVID-19. His appeal came after domestic violence hotlines around the globe reported a precipitous rise in calls following lockdown orders. In February 2020, a police station in Jinzhou received 162 reports of domestic violence during a three-month lockdown, which is exponentially higher than the 47 cases reported in all of 2019 (Coleburn et al: 2020). The effect of the prolonged confinement, financial stress and uncertainty brought about by not knowing when the pandemic ends raises tensions and animosity among couples.

In Zimbabwe, since the beginning of the lockdown, the national GBV Hotline had recorded a total of 972 GBV calls as at 22 April - an overall increase of over $70 \%$ compared to the pre-lockdown trends, (Zimbabwe Situation Report, 2020). It has been noted that the extension of the lockdown is likely to compound incidences of genderd based violence. A lot of videos and messages have been circulated on social media of women succumbing to beatings. Further exacerbating the challenge is the imposition of lockdowns, nullification of non-essential travel, and inadequately equipped medical facilities mean that most women do not get the assistance they require during this epidemic. Most police stations have been turned into camps so as to accommodate uniformed forces who are to enforce law and order during the lockdown period. Beside the fact that most of these uniformed forces are male dominated, the past experiences and history of past violence associated with the Zimbabwean uniformed forces points to an unenthusiastic approach to addressing GBV cases. This results in women not going to either the 
police stations or hospitals for fear of further victimisation. It's also a fact that during this period the police camps are heavily manned at the entrance by officers, a rigorous screening and interviewing is done before authorisation of entry into the police station and this makes it difficult for women to share their experiences. This lack of privacy and heavy screening at the police station camps, gates and on the roads deter and bar women from accessing help or reporting perpetrators of violence.

Zimbabwe had been facing electricity and water challenges prior to the outbreak of the coronavirus with most cities and towns recording weeks without receiving running water or power. However, to limit the risk of contamination of the COVID-19 virus, utmost hygienic rules must be observed at all times. Hands need to be washed thoroughly at regular intervals. According to Mhlanga and Scrumaga this constant washing of hands and hygienic measures is dependent on the ability of the Councils to provide water for the citizens. Unfortunately, almost all the councils were having challenges in getting funds for buying chemicals for water treatment. Sibanda P in the (Bulawayo Newsday, 2020) suggest that some regions in the city, prior to the Coronavirus outbreak, had gone for weeks without water. This impacts heavily and negatively on women who bear the burden of looking for alternative water sources and are forced to travel distances and queue for water without observing any social distancing rules hence exposing themselves to contamination. This is also the same for electricity which in itself is a scarce resource in Zimbabwe. The government had since introduced load shedding as means of rationing power supply. However, despite it being available in almost all towns in Zimbabwe during the lockdown period the price of electricity has increased. Most households cannot afford the price of electricity and resort to firewood which is generally sourced by women and children. However, with the travel restrictions of the lockdown, individuals cannot travel long distances thus compounding the stressful undertakings expected of women in the society. Further, due to exorbitant prices and a lack of income, gas or charcoal cannot be sources as alternative fuels during the lockdown.

As previously mentioned, governments adopt and implement several measures during pandemics in order to alleviate the adverse effects experienced by its citizens. The Zimbabwean situation has been worsened by the failure by government to access external lines of credit from the IMF and World Bank. This has severely hampered the government's response in fighting the pandemic. Government has failed to roll out widespread testing of the virus (only 3000 tests as of 15 May 2020) and giving allowances to the vulnerable groups. The government has had to rely on donations and a reallocation of its budget to finance the efforts to mitigate the spread of the virus. The reallocation of the budget has seen funds earmarked for other projects and expenditure being channelled to fight the COVID-19 pandemic. This is the case for many ministries which have had to divert from their core business and channel resources - whether human, financial, or material - to combat the COVID-19 pandemic. Though this may sound good on paper other core functions may suffer for example, sexual and reproductive health needs may not be met. Access to contraception, maternal health, menstrual hygiene products, and abortion services have reduced as the pressure of COVID-19 grows on health systems (Gwasira: 2020). The shifting of resources is substantial as this adversely impacts on women and their reproductive role. Mostly pregnant and nursing mothers, HIV and cancer patients, and all those with other conditions like diabetes and tuberculosis are heavily affected since access to medication, sanitary ware, anti-retroviral drugs, contraceptives, and baby formula is minimal due to scarcity of resources. This is worse for women in quarantine.In India, menstrual products were initially not classified for essential production (Coleburn\&Turkington, 2020).

The former Zimbabwean Minister of Health and Child Care, Obadiah Moyo, is reported as having said that government's effort to carry out malaria treatment has been greatly diminished by the outbreak of COVID-19 with all resources and efforts being channelled to fighting the virus. This could have serious consequences for pregnant women since they are particularly vulnerable as pregnancy reduces a woman's immunity to malaria, making her more susceptible to infection and increasing the risk of illness, severe anaemia and death. 
According to Mhlanga Scrumaga despite women occupying most of the health workforce they were not given major decision-making roles during the pandemic. Globally women occupy 70 percent of the global heath workforce but only hold 25 percent of senior decision-making roles. According to a Global Health 50/50 report from 2019, 72 percent of executive heads in global health are men, (Smith, 2020). As such, women are not represented in decision making bodies of COVID-19 responses. Only 5 out of the 21-member taskforce were invited to join the WHO emergency committee on the novel Coronavirus. Donald Trump's Coronavirus taskforce comprised of 12 men. The question asked is who then makes decisions on behalf of women if they are not represented since equity issues can only be integrated into emergency responses when women and marginalised groups are able to participate in decision making (Smith, 2020). On the 17th of March 2020, His Excellency the President of Zimbabwe, ED Mnangagwa declared the coronavirus pandemic a national disaster and activated the national disaster management machinery with the Ministry of Health and Child Care as lead agency. This preceded the appointment of an 11-member Ministerial Task Force to oversee the implementation of the response, including leading in mobilising resources on the 24th of March. The Ministry of Women Affairs and Gender is not part of the COVID-19 Multi taskforce. If the Ministry responsible for women affairs is not amongst this ministerial task force women's issues will not be prioritized during the fight against the pandemic.

\section{Measures to Reduce the Burden of the Pandemic to Women}

The fact that global pandemics exacerbate gender inequalities cannot be contested. The novel strain of the Coronavirus, COVID-19, has adversely affected the world's largest economies and, in its wake of destruction, has left a variety of additional socio-political challenges towards its alleviation. Women, due to their multiple roles and biological makeup, are more vulnerable to succumb to this disease. The webinar meeting from the UN Women clearly outlined the view that besides their biological disposition, women are impacted differently and negatively by the pandemic. There is, therefore, need to take a holistic approach in dealing with issues of the pandemic without ignoring the fact that women were on the receiving end and were carrying a heavy burden which left them vulnerable and highly exposed to the impact of this deadly global pandemic.

Globally, the response to the outbreak of the virus was haphazard, uncoordinated, and reactive. Various warnings went unheeded, leading to the implementation of generally inadequate control measures, with the exception of a few women-led nations like New Zealand, Germany, and Finland where the spread of the virus has been well contained. Nonetheless, the abruptness of implemented measures has resulted in additional challenges. For example, several citizens were caught in transit and unable to return home without help from their home governments. Some are still held up in foreign lands with little prospects of finding their way home due to most airlines having suspended flights. Accusations and counter accusations have been the order of the day with the US government going to the extent of withdrawing its funding to the World Health Organisation. This has the effect of incapacitating WHO at this critical juncture. Whilst the race is still on for a vaccine to be found, Madagascar has already declared that they have found a cure. With better coordination and proactivity the effects of the disease could have been minimised. There is, however, still hope when taking it from the words of the US President Donald Trump who intimated that the solution to the Coronavirus pandemic cannot be worse than the problem.

Zimbabwe is now on level 2 of the lockdown where there is limited movement of people and the opening up of formal businesses, agricultural sector, manufacturing sector and mining sector. With strict adherence to social distancing, good hygienic practices, wearing of masks, screening of people as they visit stalls and markets and more education on the do's and don'ts to limit the spread of the Coronavirus, the informal sector can be opened up so that people can go back to work and earn a living. Governments need to put on a gender lens when coming up with measures to curb the spread of the 
virus. Women should be included in the main taskforces of the coronavirus teams and be given major decision-making roles to decide on issues that affect them. Since most women fall in the informal sector, the government should go down to ward level through structures such as Agritex in rural areas and through councillors in urban areas to start distributing meaningful cushioning allowances and food hampers for the masses. A non-partisan database for all vulnerable groups must be compiled through traditional heads so that all Zimbabweans who need assistance benefit. In cases of domestic or genderbased violence, there is need for awareness campaigns through social media and an increase in the number of toll-free lines for social and psychological support for women.

Government needs to ensure basic commodities availability and to reign in on retailers who are continuously increasing prices of basic commodities. Government may also close down such retailers to serve as an example to other would be defaulters. Urgent solutions are also required to manage water reticulation services throughout the nation. Funding should be immediately disbursed to Councils so that potable water can be accessed in homes. At the same time, the Zimbabwean police are supposed to prosecute water barons who position themselves as heads of boreholes at the same time demanding for payments for water from women and children. The price of electricity and telone charges for Wi-Fi services to be minimal and affordable so as to encourage online interaction and reduce time spent in search of alternative fuels and improve social distancing. There is need for the public relations wing of the army and police to overhaul their interaction with the people so that they regain and restore public confidence. Further, uniformed forces must take back and embrace the role of being the protector, not abuser so that they are approachable in case of any abuse. There is also urgent need for government to review sanitation issues as a priority in women's health. Sanitary ware, diapers, formula and baby clothing industries should be among the essential services and should be opened. The government should seriously roll out awareness campaigns and programs to address issues of patriarchy and toxic masculinity so as to reduce cases of gender based violence which are on the rise.

\section{Conclusion}

This study has presented socio-economic impact of COVID-19 among girls and women in Zimbabwe which is based on the webinar hosted by UN Women in Zimbabwe. The study concludes that women are severely impacted by this pandemic (COVID-19). Also, from the findings it is depicted that COVID-19 pandemic poses a significant threat to global health and security. Likewise, more has to be done to reduce its negative impact on women as a central component of both global health and security reassurance efforts. There has also been a general lack of coherence on the global stage in the fight of the disease which have impacted overall human kinds however, women seems to have greater impact of the pandemic directly or indirectly.

\section{Conflict of Interest}

Author declares no conflict of interest existed while preparing this article.

\section{References}

Beech, P. (2020, April 4). Covid-19-coronavirus-pandemic-hit-women-harder-than-men/World Economic Forum. Retrieved from https://www.weforum.org/age

Coleburn M, Turkington R. (2020, June), Women week gendered effects COVID-19, Retrieved from https://www. cfr.org

Dhatt, R., Keeling, A. \& Soraki, T. (2020,April 3). Fighting COVID-19 with one hand tied behind our backs, Think Global Health. Retrieved from https://www.thinkglobalhealth.org

Farran, A.G. (2020, April). UN chief calls for domestic violence 'ceasefire' amid 'horrifying global surge"'. UN News. Retrieved from, https://news.un.org/en/story/2020/04/1061052 
Forde, K. (2020, April 3). Aljazeera, Retrieved from https:/www.aljazeera.com/profile/.html,

Gwasira, M. (2020, May 17). Zim Experts Warn of Rise In Unintended Pregnancies After Lockdown...Should Young People Adopt Long-term Contraceptives? The Health Times, Retrieved from https://healthtimes. co.zw/2020/04/19/

Johnson, K. (2020, June). Covid-19 coronavirus: Domestic violence is the second, silent epidemic amid lockdown. NZ Herald

Mhlanga, P. (2020). Presentation. Mapping Gendered Impacts of COVID 19 and the National Response - C Plenary Session

NGOs intervene in Bulawayo Water Crisis, (2020 October 12). Newsday, Zimbabwe https://www.newsday.co.zw

Serumaga, D. (2020). Presentation. Mapping Gendered Impacts of COVID 19 and the National Response - C Plenary Session

Smith, J. (2020, February 4).Gender and the corona virus outbreak,Think Global Heath, Retieved from https:// www.thinkglobalhealth.org/article/gender-and-coronavirus-outbreak

The Impact of COVID-19 on Women, (2020 April 9). United Nations Policy Brief.Retrievedfromhttps://unsdg. un.org/resources/policy-brief-impact-covid-19-wom

Women girls health workers must not be overlooked global covid 19-response, UNFPA Brief (2020). Retrieved from https://www.unfpa.org/

Zimbabwe Situation Report. (2020 April 29). Retrieved from https://reliefweb.int/report/zimbabwe/zimbabwesituation-report-29-apr-2020 